\title{
Can molluscan assemblages give insights into Holocene environmental changes other than sea level rise? A case study from a macrotidal bay (Marennes-Oléron, France)
}

\author{
Clément Poirier ${ }^{\mathrm{a},}{ }^{*}$, Pierre-Guy Sauriau $^{\mathrm{a}, \mathrm{b}}$, Eric Chaumillon $^{\mathrm{a}}$ and Jonathan Allard ${ }^{\mathrm{a}}$ \\ a LIENSs, LIttoral, ENvironnement, Sociétés, Université de La Rochelle, CNRS, 2 rue Olympe de Gouges, 17000 \\ La Rochelle, France \\ ${ }^{b}$ ELA, Environnement Littoral Atlantique, Ifremer, CNRS, place Gaby Coll, BP 5, 17137 L'Houmeau, France
}

\begin{abstract}
*: Corresponding author : C. Poirier, Tel.: +33 546507644; fax: +33 546458274, email addresses : clement.poirier@univ-Ir.fr, pierre.guy.sauriau@ifremer.fr (P.-G. Sauriau), eric.chaumillon@univ-Ir.fr (E. Chaumillon), jonathan.allard@univ-Ir.fr (J. Allard)
\end{abstract}

\begin{abstract}
:
During the Late Holocene, the rate of sea level rise decreased and climate changes, hydrodynamic processes or anthropogenic impacts became predominant parameters governing the sedimentary infill of estuarine environments. The aim of this study is to describe the response of past benthic mollusc communities to these forcing factors. Mollusc skeletal remains were sampled from three 8000,5500 and 2600 year-long sedimentary records in the Marennes-Oléron Bay (Atlantic Coast, France), where environmental changes have previously been identified thanks to a combination of very high resolution seismic profiles and sedimentological data. Molluscan assemblages successfully record environmental changes, even at the smallest temporal scale. They provide relevant information regarding bathymetry, salinity, hydrodynamics, oxygen content and sediment supply. In the 8000 year-long record, the transition from an upper to a lower intertidal mudflat community provides evidence of a transgressive phase that occurred between 8000 and 7600 years BP. In the 5500 year-long record, an oyster bank developed on the slopes of a tidal channel has been recovered. The composition of the fossil community and the careful examination of skeletal remains suggest that the channel was hydraulically inefficient, in response to the sediment infilling of its drainage area. In the 2600 year-long record, a soft-bottom, shallow-water, subtidal mollusc community, similar to that found nowadays in the Marennes-Oléron Bay, has been recovered from both lower mixed sand-mud and upper muddy units separated by a major regional unconformity dated to about 1000 years BP. This sharp transition is recorded by a few rare species, and was responsible for the local extinction of the bivalve Lepton squamosum. However, the abundance of the most common species and the quantity of fragmented shells remain stable, which may indicate that mud drape deposition was related to an increase in mud supply rather than a decrease in water energy. The level of detail of the palaeoenvironmental reconstructions varies, depending on the ecological requirements of the species. Stenotypic indicator species provide accurate, quantitative information, whereas eurytypic species add undesired variability to the assemblages. Since fossil molluscs are easy to collect and to identify and provide long-term, smoothed records of environment variations, this study suggests that they can be used prior to any other biological proxy, as a first step into reconstructions of Holocene coastal environments.
\end{abstract}

Keywords: Macrofauna; Death assemblage; Palaeoenvironment; Sediment core; Atlantic Coast 


\section{Introduction}

Among the many taxa used in palaeoenvironmental reconstructions, molluscs are particularly useful (Boucot, 1981). Their skeletal remains are well preserved in the sedimentary record and up to $74 \%$ of known living bivalves are also known as fossils (Valentine et al., 2006). They are large-sized and thus easier to collect and identify than microfossils such as foraminifers or ostracods. Molluscs belong to well described taxonomic groups, for which a considerable amount of literature is available (Costello et al., 2001). Their ecological requirements have also been accurately studied, at least for the most common species (e.g. Tebble, 1966; Cadée, 1968; Graham, 1988). Benthic surveys that describe the structure of macrofaunal communities in response to environmental conditions pervade the literature (Pérès and Picard, 1964; Wolff, 1973; Hily, 1976; Sauriau et al., 1989; de Montaudouin and Sauriau, 1999; Ysebaert et al., 2000).

Mollusc death assemblages usually contain more species than live communities within a given area (Kidwell, 2002). This excess of dead species partly results from postmortem transportation of individuals. Most of the time however, it is a consequence of timeaveraging, i.e. the accumulation of successive communities in the Taphonomically Active Zone (Davies et al., 1989). Taphonomic processes are involved in post-mortem destruction of remains. Despite these biases, composition of present-day death assemblages often reflects the original rank frequency distribution of live species in communities (Kidwell, 2002). Species that are abundant alive also dominate death assemblages, and conversely rare live species are also rare dead. Molluscan assemblages are thus fairly reliable records (Boucot, 1981).

Many authors have used molluscan assemblages to characterise Holocene coastal palaeoenvironments, sometimes as a complement to other biological proxies such as foraminifers (Borrego et al., 1999; Bernasconi et al., 2006). However, most of these publications have reported long-term sedimentary records over 10,000 to 8,000 years BP (Taldenkova et al., 2005; Zinke et al., 2005; Ivanova et al., 2007, Allard et al., 2008). During this period, sedimentation was mainly controlled by the rapid rise of sea level (Goy et al., 1996; Long et al., 2000; Freitas et al., 2002; Allard et al., 2008). The rapid retreat of coastlines during the early Holocene is recorded by major changes in the composition of molluscan assemblages. Depending on chronology and local variations in geomorphology, these changes consist of the transition from freshwater (Ivanova et al., 2007) or brackish (Taldenkova et al., 2005; Zinke et al., 2005; Allard et al., 2008) to marine communities. The influence of other factors such as climate forcing (Goy et al., 1996), hydrodynamic processes (Long et al., 2000) or anthropogenic impacts (Freitas et al., 2002) became predominant after 6,000 years BP, as sea level rise progressively slowed down. Few mollusc fossil records within this period have been published (Sauriau and Gruet, 1988; Gruet and Sauriau, 1994).

The aim of this study is to describe the response of molluscs to environmental changes during the Holocene. Molluscs were sampled from three 8,000, 5,500 and 2,600 year-long sedimentary records in the Marennes-Oléron Bay (Atlantic Coast, France), where environmental changes have previously been identified thanks to very high resolution seismic profiles ground-truthed by sedimentological data (Chaumillon et al., 2004; Billeaud et al., 2005; Allard et al., 2008). Environmental conditions prevailing in fossil assemblage records are deduced from background information on benthic surveys of the present-day macrofauna from the study area (Hily, 1976; Sauriau et al., 1989; de Montaudouin \& Sauriau, 1999). Successions of fossil assemblages are described and compared to an 8,000 year-long reference record of Holocene marine transgression published by Allard et al. (2008), in which the transition from intertidal to subtidal communities has been demonstrated. Features of the palaeoenvironmental reconstructions are then described and compared. 


\section{General setting}

\subsection{Geographical framework}

The Marennes-Oléron Bay is located in the middle part of the Atlantic Coast of France (Fig. 1a). It is an about $200 \mathrm{~km}^{2}$, semi-enclosed shallow bay (maximum depth $20 \mathrm{~m}$ ), bounded by the Oléron Island to the west and the mainland to the east. The bay is connected to the Atlantic Ocean through two entrances (Fig. 1b), the wide Pertuis d'Antioche to the north and the narrow Maumusson Inlet to the south. Intertidal areas represent about $50 \%$ of the bay and mainly consist in bare mudflats, except on both the east coast of Oléron Island and southern parts of the bay, where Zostera noltii seagrass grow. The tidal regime is semidiurnal, ranges from less than $2 \mathrm{~m}$ (neap tides) to more than $6 \mathrm{~m}$ (spring tides), and controls turbidity levels (Raillard and Ménesguen, 1994), as well as wind waves. Swells predominantly coming from the W-NW direction penetrate in the bay through the Pertuis d'Antioche and are strongly attenuated due to wave refraction. Two small rivers flow into the bay: the Seudre River to the south, and the Charente River to the east which contributes more than $90 \%$ of the total freshwater input. The Marennes-Oléron Bay is both under a continental influence to the east (Charente River turbid plume) and an oceanic influence to the west (swell refraction). Due to this east/west dichotomy, muddy bottoms are predominant in the eastern part of the bay and sandy mud bottoms along the coast of Oléron Island (Sauriau et al., 1989). The study area is located in the Rade des Trousses Channel, which corresponds to the northern part of the Marennes-Oléron bay (Fig. 1c).

\subsection{Present-day mollusc communities}

On the basis of a biosedimentary classification (Chassé and Glémarec, 1976), Hily (1976) first described the macrofaunal communities living in Pertuis d'Antioche and Marennes-Oléron Bay. Sauriau et al. (1989) and de Montaudouin and Sauriau (1999) completed this work with quantitative surveys of benthic molluscs at 370 and 262 sampling stations respectively, located within the Marennes-Oléron Bay. Hily (1976) noticed that both sedimentary features and bottom currents in the Rade des Trousses area allowed rich macrofaunal communities to develop. This observation was subsequently supported by Sauriau et al. (1989), who found up to 16 mollusc species in this area. Two subtidal communities, related to mud and sandy mud bottoms, coexist in the Rade des Trousses area (Table 1; de Montaudouin and Sauriau, 1999). Both communities have many similar mollusc species, although species richness is higher on sandy mud bottoms ( 25 species) than muddy bottoms (12 species). Some species such as Abra nitida, Corbula gibba and Nucula nitidosa are distinctive of the mud community, whereas Kurtiella (= Mysella) bidentata, Nassarius pygmaeus and Cylichna cylindracea are characteristic of the sandy mud community (Table 1).

\subsection{Holocene sedimentary infill}

The Holocene sedimentary infill of the western (Chaumillon et al., 2004; Billeaud et al., 2005; Chaumillon and Weber, 2006), central (Bertin and Chaumillon, 2005) and eastern (Allard et al., 2008) Marennes-Oléron bay has been investigated with very high resolution seismic surveys ground-truthed by sediment cores. It can be grouped in four main stratigraphic units (Fig. 2):

(1) Unit U1 consists of two different sedimentary bodies. To the west, unit UT1 (UT1 in Chaumillon et al., 2004 and Billeaud et al., 2005; Uaid1 in Chaumillon and Weber, 2006) consists of small lenses overlying the incised Mesozoic bedrock (U0). To the east, unit Ue1 
(U1 in Allard et al., 2008) is a valley fill lying upon the incised Mesozoic bedrock (U0). It was dated to $8030 \pm 50$ years BP and $7610 \pm 40$ years BP (Allard et al. , 2008).

(2) Unit U2 consists of two different sedimentary bodies. To the west, unit UT2 (UT2 in Chaumillon et al., 2004 and Billeaud et al., 2005; Uaid2 in Chaumillon and Weber, 2006) is a thick (max. $13 \mathrm{~m}$ ) valley fill overlying both the bedrock and unit Ue1/UT1. Its upper boundary is a regional erosional unconformity named EU1, which is recorded in sediment cores as a $40 \mathrm{~cm}$ thick shell bed (Billeaud et al., 2005; Allard et al., 2008). It is mainly composed of relatively coarse-grained sediments (fine to medium sands) dated to $2695 \pm 30$ years BP and $2205 \pm 30$ years BP (Chaumillon and Weber, 2006). To the east, unit Ue2 consists of a drape lying on unit Ue1.2 and on the slopes of the Mesozoic bedrock (Allard, 2008).

(3) Unit U3 consists of two different sedimentary bodies. To the west, unit UT3 is a large (5 km long, $2 \mathrm{~km}$ wide) progradational body (UT3 in Chaumillon et al., 2004 and Billeaud et al., 2005; Uaid3 in Chaumillon and Weber, 2006), the upper boundary of which is a toplap surface. To the east, unit Ue3 is a thick (max. $8 \mathrm{~m}$ ) channel fill (U3 in Allard et al., 2008), the upper boundary of which is the regional unconformity EU1.

(4) Unit UT4 (UT4 in Chaumillon et al., 2004 and Billeaud et al., 2005; Uaid4 in Chaumillon and Weber, 2006; U4 in Allard et al., 2008) is a thin (max. $3 \mathrm{~m}$ ) sheet drape that progressively thins northward and eastward. Its upper boundary corresponds to the presentday seafloor. It is composed of very fine estuarine muds dated to $860 \pm 25$ years BP and $1230 \pm 30$ years BP (Chaumillon and Weber, 2006). Several hypotheses have been proposed to explain the deposition of this regional mud (mainly silt) drape (Chaumillon et al., 2004; Billeaud et al., 2005). It was interpreted as being a consequence of a decrease in hydrodynamic energy and/or an increase in sediment supply. Decrease in hydrodynamic energy may be related to natural sediment infilling of the bay and adjacent marshes, amplified by land reclamation and related decrease of tidal prism. Increase in sediment supply may be related to expulsion of suspended matter to the outer estuary, following the sediment infilling of the inner estuary, and/or late Holocene climate changes (transition from Medieval Warm Period to Little Ice Age), and/or forest clearances since the Middle Ages.

\section{Material and methods}

\subsection{Vibracore sampling}

During MOBIDYC5 cruise (June 2006, CNRS-INSU Côte de la Manche vessel), 56 vibracores were collected. Five vibracores were selected: vibracore VC47 was selected in order to ground-truth the stratigraphic units in the eastern part of the study area (as well as reference core VC48, Allard et al., 2008) and vibracores VC14, VC22, VC28 and VC30 in the western part of the study area (Figs. 1c and 2). Cores were transversally opened, described, photographed, X-radiographed (SCOPIX, Migeon et al., 1999), and sampled for grain-size analyses. Sampling for grain-size analysis was selective in that samples were collected only where X-ray images and grey-level curves showed noticeable changes. Grain size distributions of sediment samples were measured with a microgranulometer (Mastersizer S instrument, Malvern Instruments). Inman's classification (Inman, 1952) was used to define the various grain-size fractions: clay to fine silt $(<15 \mu \mathrm{m})$, medium silt $(15-30 \mu \mathrm{m})$, coarse silt $(30-63 \mu \mathrm{m})$ and very fine to fine sand $(>63 \mu \mathrm{m})$. A P-wave velocity interval of $1580-1720$ $\mathrm{m} . \mathrm{s}^{-1}$ was chosen for correlation between the cores and the seismic profiles, according to the relationship between P-wave velocity and the $30 \mu \mathrm{m}$ mean grain size of the sampled sediment. Elevation data are given according to the NGF system (Nivellement Général de la France), the reference $0 \mathrm{~m} \mathrm{NGF}$ being the mean tidal level at Marseille. 


\subsection{Sampling processing}

Mollusc skeletal remains were recovered from 119 bulk samples, 26 from core VC47 and 18, 19, 25, and 31 from cores VC14, VC22, VC28, and VC30, respectively. Sampling was selective where conspicuous shells were visible or revealed by X-ray images. When no shells could be found, sediment was sampled at about $25 \mathrm{~cm}$ intervals. In order to avoid biases in data analysis, samples from the Taphonomically Active Zone (Davies et al., 1989) were not taken into account. In this sub-surface layer, taphonomic processes affect the present-day mollusc death assemblage and modify its composition. In our cores, it corresponded to a $20 \mathrm{~cm}$ thick layer, in which the recently introduced non-native species Crepidula fornicata L., 1758 was found (Sauriau et al., 1989; de Montaudouin and Sauriau, 1999). Samples from the EU1 shell bed were not considered either, as mollusc skeletal remains showed significant signs of reworking.

Bulk samples were carefully water-sieved on a $500 \mu \mathrm{m}$ mesh. Mollusc skeletal remains were sorted and identified at the species level when possible, in accordance with ERMS taxonomic nomenclature (Costello et al., 2001). Skeletal remains of three genera could not be identified up to the species level. Identification of the different Abra species living along the French Atlantic coast is based on the lateral teeth of the right valve and on the size of the pallial sinus (Glémarec, 1964). These features were difficult to see when skeletal remains were broken or corraded. Due to their small size, the pyramidellid gastropods Chrysallida sp. and Odostomia sp. were commonly corraded and thus also difficult to identify. However, as these three genera represented an important part of the molluscan assemblages, they were taken into account for data analysis. When broken remains were found, only those with intact hinge lines for bivalves and apex or peristome for gastropods were counted, even if those fragments were recognizable thanks to characteristic colour and/or ornamentation. Gastropods and intact bivalves were counted as 1 specimen, and disarticulated valves were counted as 0.5 . Mollusc skeletal remains belonging to the same species were grouped together and weighed with a $10 \mathrm{mg}$ precision scale. Corrasion (i.e. corrosion due to chemical destruction and/or abrasion due to transport, Brett and Baird 1986) of skeletal remains was observed. Preservation of assemblages was estimated by comparing the relative quantity of non-identifiable fragmented remains (mass values) with the relative quantity of well preserved identified remains. The same methodology was followed for the 17 samples recovered by Allard et al. (2008) from reference core VC48.

Dating of stratigraphic units was based on radiocarbon dating carried out by the AMS method by Poznań Radiocarbon Laboratory (Poznań, Poland). Nine mollusc specimens or valves of Scrobicularia plana, Loripes lacteus, Ostrea edulis and Abra sp. were chosen based on ecological and taphonomic criteria, following the recommendations of Fujiwara et al. (2004). Calibration of radiocarbon ages was not applied.

\subsection{Data analysis}

Molluscan assemblages were described after removing rare species that represented less than $1 \%$ of the total relative species abundance from each core. Data consisted of two $n$ samples $\times p$ species matrices, containing abundance and mass values respectively, and included samples from reference core VC48. Data analysis was performed using software R 2.6.2 (R Development Core Team, 2008).

The first step of data analysis consisted of building a presence/absence (1/0) matrix, regardless of species abundance or mass. This provided a simplified representation of the composition of the molluscan assemblages within each core. Principal Component Analysis (PCA) was performed on relative abundance values after $\log _{10}(x+1)$ transformation, in order to identify characteristic groups of species within the fossil assemblages. Further data analysis was applied to biomass data. Relative mass-weighted abundance values were calculated as following: $\left(\left(a_{i j} \times \mathrm{ms}_{i j}\right) / \mathrm{sum}^{n}{ }_{j=1}\left(\mathrm{ab}_{\mathrm{ij}} \times \mathrm{ms}_{\mathrm{ij}}\right)\right) \times 100$ (ab indicates abundance values and ms mass values). Kruskal-Wallis tests were performed on those values in cases where PCA failed to show significant variations in relative species abundance. 


\section{Results}

\subsection{Sedimentological data}

In the eastern part of the Rade des Trousses area, sedimentary records are obtained by the M4b38 seismic profile and the cores VC48 and VC47 (Fig. 2). Core VC48 is $424 \mathrm{~cm}$ long and cuts through stratigraphic units UT4 and Ue1.2; core VC47 is $403 \mathrm{~cm}$ long and cuts through stratigraphic units UT4 and Ue3 (Fig. 3). In the western part of the Rade des Trousses area, the sedimentary record is obtained by the seismic profiles LSTULR6-33 and LSTULR6-37 and the cores VC14, VC22, VC28 and VC30 (Fig. 2). These four cores are 406, 373,351 , and $390 \mathrm{~cm}$ long, respectively, and cut through stratigraphic units UT4 and UT2 (Fig. 4). As unit UT4 progressively thins northward (Fig. 2), core VC14 does not cut through unit UT2, whereas it is the thickest unit in core VC30 (Fig. 4). Correlation between the four cores is done on the basis of seismic stratigraphy, grain size data, and X-ray images (Fig. 4).

\subsubsection{Sub-unit Ue1.2 (8030 \pm 50 years to $7610 \pm 40$ years BP)}

Sub-unit Ue1.2 is sampled only by reference core VC48, from -11.2 to $-9.1 \mathrm{~m}$ NGF (Fig. 3). Sediment is composed of clay and fine silt, coarsening upward to coarse silt. X-ray images do not show any physical structures (i.e. erosional surface, laminae of fine sediments) but abundant and apparently well preserved molluscan remains. Sub-unit Ue1.2 is dated to $8030 \pm 50 \mathrm{BP}$ at $-11.1 \mathrm{~m}$ NGF (Scrobicularia plana specimen, reference Poz20099) and to $7610 \pm 40 \mathrm{BP}$ at $-9.4 \mathrm{~m}$ NGF (Loripes lacteus valve, reference Poz-20100).

\subsubsection{Unit Ue3 (5560 \pm 40 years to $5130 \pm 35$ years BP)}

Unit Ue3 is sampled only by core VC47, from -10.9 to -9.0 m NGF (Fig. 3). Sediment is composed of clay and fine silt. Abundant and large molluscan remains are visible. Unit Ue3 is dated to $5560 \pm 40 \mathrm{BP}$ at $-10.4 \mathrm{~m}$ NGF (Ostrea edulis specimen, reference Poz-23455) and to $5130 \pm 35 \mathrm{BP}$ at $-9.2 \mathrm{~m}$ NGF (O. edulis specimen, reference Poz-23457).

\subsection{3. nit UT2 (from $2600 \pm 30$ years to $1695 \pm 30$ years BP)}

Unit UT2 is sampled by cores VC22 from -15.5 to -14.8 m NGF, VC28 from -17.2 to $16.7 \mathrm{~m} \mathrm{NGF}$, and VC30 from -18.3 to $-15.5 \mathrm{~m}$ NGF (Fig. 4). Sediment is mainly composed of very fine and fine sand. X-ray images reveal abundant molluscan remains, and few signs of bioturbation. Unit UT2 is dated to $2600 \pm 30 \mathrm{BP}$ at $-18.1 \mathrm{~m}$ NGF in core VC30 (Abra sp. valve, reference Poz-20105) and to $1695 \pm 30 \mathrm{BP}$ at $-14.8 \mathrm{~m}$ NGF in core VC22 (Abra sp. valve, reference Poz-20106).

\subsubsection{Unit UT4 (from $910 \pm 30$ years BP to the present)}

Unit UT4 is sampled by cores VC48 from -8.6 to -7.0 m NGF and VC47 from -8.5 to $6.9 \mathrm{~m}$ NGF (Fig. 3) and by cores VC14 from - 13.9 to $-9.8 \mathrm{~m}$ NGF, VC22 from -14.6 to -11.8 $\mathrm{m}$ NGF, VC28 from -15.1 to $-13.7 \mathrm{~m}$ NGF and VC30 from -15.3 to $-14.4 \mathrm{~m} \mathrm{NGF} \mathrm{(Fig.} \mathrm{4).}$ Sediment is composed of clays (VC14) to coarse silts (VC48), and displays horizontal laminae of very fine sand, except in areas of intense bioturbation where bedding structures are not preserved. Sediment contains few molluscan remains, particularly in core VC14 (Fig. 4). Unit UT4 is dated to $630 \pm 30 \mathrm{BP}$ at $-7.8 \mathrm{~m}$ NGF in core VC48 (Abra sp. valve, reference Poz-20250), to $625 \pm 30 \mathrm{BP}$ at $-14.0 \mathrm{~m}$ NGF in core VC28 (Abra sp. valve, reference Poz20104), and to $910 \pm 30$ BP at -14.6 m NGF in core VC22 (Abra sp. valve, reference Poz20122). 


\subsection{Molluscan assemblages}

A total of 72 different species is identified. Among them, 27 represent more than $1 \%$ of the assemblages and are thus selected for Principal Component Analysis (PCA), which is performed on values of relative species abundance (Fig. 5). The first 3 loadings of the PCA accounts for $39.59 \%$ of the total inertia (axis 1: 18.10\%; axis 2: $13.47 \%$; axis 3: $8.02 \%$ ). Five mollusc fossil associations can be recognised. Species names are coded as the first four and three letters of the genus and species names, respectively (e.g. Hydr ulv for Hydrobia ulvae). Association names are those of the most common species:

(1) Scrobicularia association: It is composed of two intertidal mudflat species, Scrobicularia plana and Hydrobia ulvae (Fig. 5b).

(2) Rissoa association: It is composed of four intertidal mudflat species Rissoa membranacea, Parvicardium exiguum, Loripes lacteus, and Mytilus edulis. Three allochthonous species living on intertidal rocky shores, Gibbula cineraria, Tricolia pullus and Haliotis tuberculata are also found with this association (Fig. 5a).

(3) Ostrea association: It is composed of the flat oyster Ostrea edulis and its predator Ocenebra erinacea (Fig. 5b).

(4) Tornus association: It is composed of the gastropod Tornus subcarinatus and the epibenthic filter-feeding bivalves Anomia ephippium and Chlamys varia (Fig. 5b).

(5) Spisula association: It consists of soft-bottom, shallow-water, subtidal species such as Spisula subtruncata, Abra sp., Nucula nitidosa, Turbonilla lactea, Corbula gibba, Chrysallida sp., Kurtiella bidentata, Antalis novemcostata, Turritella communis, Partulida spiralis, Nassarius pygmaeus, Odostomia sp., and Pandora inaequivalvis (Fig. 5a).

\subsubsection{Presence-absence data}

\subsubsection{Sub-unit Ue1.2: Scrobicularia and Rissoa associations}

The presence-absence matrix reveals the occurrence of two distinct molluscan assemblages within sub-unit Ue1.2 (Fig. 6). In its lower part (from -11.2 to -10.5 m NGF), the Scrobicularia association is found in seven samples, together with few Parvicardium exiguum valves in 3 samples. Total species richness does not exceed three species. Skeletal remains are intact, but shells are severely corraded (chalky aspect). In the upper part of sub-unit Ue1.2 (from -10.0 to -9.1 m NGF), the Rissoa association is found in seven samples. Total species richness varies from 2 to 9 species. Skeletal remains of autochthonous (mudflat) species are very well preserved, whereas skeletal remains of allochthonous (rocky shores) species show signs of corrasion.

\subsubsection{Unit Ue3: Ostrea, Tornus and Spisula assemblage}

The presence-absence matrix shows the presence of the flat oyster Ostrea edulis in all of the 21 samples within unit Ue3 (Fig. 7). Shells are abraded, but articulated specimens are more common than disarticulated valves. Additional species occur also in the lower (from -10.9 to $-10.4 \mathrm{~m}$ NGF) and upper parts (from -9.7 to $-9.0 \mathrm{~m} \mathrm{NGF)} \mathrm{of} \mathrm{unit} \mathrm{Ue3.} \mathrm{In} \mathrm{these}$ samples, the Ostrea association is combined with the Tornus association and reworked elements of other species such as $P$. exiguum (Rissoa association) or Abra sp. and $N$. nitidosa (Spisula association). These skeletal remains are broken and corraded. Total species richness varies from 2 to 18 species. 


\subsubsection{Units UT2 and UT4: Spisula and Tornus assemblage}

All of the five association are found in units UT2 and UT4 (Fig. 8), except the Scrobicularia association. Total species richness shows considerable variation between samples, and varies from 1 to 24 species. The bivalves Spisula subtruncata, Abra sp., Nucula nitidosa and Kurtiella bidentata from the Spisula association are the most recurrent species in this assemblage, together with Anomia ephippium and Chlamys varia from the Tornus association. Other species occur randomly in the samples. Significant changes in the composition of this fossil assemblage cannot be recognised, neither between nor within UT2 and UT4 units.

\subsubsection{Relative species abundance}

Relative species abundance values are compared using Principal Component Analysis. Plot of PCA scores (Fig. 9) reveals groups of points that match the associations previously identified by the presence-absence matrix analysis. Between-groups variability varies inversely to within-groups variability. In core VC48, the plot shows three well separated groups of points (Fig. 9a), which corresponds to the Scrobicularia (lower part of sub-unit Ue1.2), Rissoa (upper part of sub-unit Ue1.2) and Spisula (unit UT4) associations respectively. Within-groups variability is low, except for the Rissoa association. In core VC47, the plot shows two overlapping groups of points (Fig. 9b), which correspond to the OstreaTornus (unit Ue3) and Spisula-Tornus assemblages (unit UT4), respectively. Betweengroups variability is lower than for core VC48, as points partially overlap. Conversely, withingroup variability is higher. In cores VC14 to VC30, between-groups variability is zero, since the plot shows only one compact group of points (Fig. 9c) that corresponds to the SpisulaTornus assemblage found in units UT2 and UT4 (Fig. 8). The highest within-group variability is found here, particularly in samples from unit UT2.

\subsubsection{Relative mass-weighted species abundance}

Since no significant changes in the composition and diversity of the molluscan assemblages in the sedimentary record of the western Rade des Trousses can be recognised (see VC14, VC22, VC2 and VC30), Kruskal-Wallis tests are performed on relative mass-weighted species abundance values. All the species, including the rare ones, are taken into account for this analysis. Samples from unit UT2 $(n=32)$ versus unit UT4 $(n=24)$ are compared. Tests are significant $(p<0.05)$ for 7 species (Table 2). Among them, three species (i.e. Nucula nitidosa, Parvicardium exiguum and Barnea candida) are more abundant in unit UT4 than in UT2. Conversely, the four other species (i.e. Turritella communis, Turbonilla lactea, Thyasira flexuosa, and Lepton squamosum) are more abundant in unit UT2 than in UT4 (Fig. 10). B. candida is totally absent from unit UT2 and L. squamosum from unit UT4 (table 2). The relative quantity of non-identifiable fragments does not significantly change (Kruskal-Wallis test, $p=0.68)$ between UT2 $(56.3 \pm 18.8 \%)$ and UT4 $(56.0 \pm 21.4 \%)$.

\section{Discussion}

\subsection{Palaeoenvironmental interpretation of the molluscan assemblages}

5.1.1. Sub-unit Ue1.2: high to low intertidal mudflat 
The two distinct assemblages identified in sub-unit Ue1.2 have been related to two different environments (Allard et al., 2008). The Scrobicularia association (lower part of subunit Ue1.2) is typical of a high intertidal bare mudflat (Welsh, 1919) similar to that found nowadays along the eastern part of Marennes-Oléron Bay (Sauriau et al., 1989; Gouleau et al., 2000). Present-day Scrobicularia plana lives in brackish waters of 16 to 25 (Tebble, 1966), which indicates that this palaeo-mudflat was subject to freshwater input, probably because of the proximity to the Charente River turbid plume. Absence of allochthonous species (e.g. rocky shore species) also suggests a bare mudflat located far away from vegetated rocky outcrops.

The Rissoa association (upper part of sub-unit Ue1.2) is typical of a lower intertidal mudflat, vegetated by Zostera seagrass (Blanchet et al., 2004). Rissoa membranacea indicates a greater marine influence compared to the Scrobicularia assemblage, since it lives in brackish to marine waters of 20 to 35 (Graham, 1988). The occurrence of Parvicardium exiguum indicates high organic matter content in the sediment (Lastra et al., 1993) that could lead to locally anoxic conditions, as suggested by the presence of Loripes lacteus (Tebble, 1966). The allochthonous gastropods Gibbula cineraria, Tricolia pullus and Haliotis tuberculata live on intertidal rocky shores covered by algal turfs around the low-water springtide level (Graham, 1988). G. cineraria can stand salinities as low as 25 and prefers sheltered areas (Graham, 1988), as does H. tuberculata (Clavier and Chardy, 1989). These species suffered post-mortem transport, and probably lived on the interfluves of the valley shown on the M4b38 seismic profile (Fig. 2) or on adjacent rocky outcrops (Fig. 1C).

\subsubsection{Unit Ue3: oyster bank}

The Ostrea-Tornus assemblage is typical of an oyster bank growing on the slopes of a channel. Anomia ephippium and Chlamys varia are epibenthic bivalves that require a hard substrate such as oyster shells to grow. Tornus subcarinatus is a small gastropod that usually lives close to oyster banks and requires a well oxygenated sediment (Graham, 1988). Some broken and corraded remains of subtidal species are also found in unit Ue3. These must have been transported post-mortem in a landward direction. Careful examination of skeletal remains provides relevant information about the hydrodynamic regime in the channel. T. subcarinatus has a thin and brittle shell that easily breaks, so it lives in sheltered places. Most of its remains in unit Ue3 are found intact, with few signs of fragmentation and corrasion, which suggests that currents in the Ue3 channel were weak. This assumption is supported by the occurrence of articulated Ostrea edulis. These oyster shells did not undergo significant reworking, thus radiocarbon dating of the Ue3 channel fill is reliable.

\subsubsection{Units UT2 and UT4: shallow water subtidal area}

The Spisula association found in units UT2 and UT4 is typical of a shallow-water, subtidal, soft-bottom community similar to that described in the Rade des Trousses area by Hily (1976), Sauriau et al. (1989) and de Montaudouin and Sauriau (1999). In this area, the sedimentary infill consists of thick mixed silt and fine sand bodies (unit UT2) overlain by a Recent estuarine mud drape dated to $910 \pm 30$ years BP (unit UT4). One might expect that such a dramatic change was responsible for transition from a sandy mud to a mud mollusc community, but the composition (presence/absence data, Fig. 8) and structure (abundance data, Fig. 9c) of the molluscan assemblages remain remarkably stable for over 2,600 years. Both time-averaging and local geomorphology may explain this apparent stability. The western part of the Rade des Trousses area is a semi-enclosed environment, influenced by the turbid plume of the Charente River to the east and by swell refraction to the west. The composition of the mollusc community in this area may have varied depending on the relative contribution of these two factors that provide fine- and relatively coarse-grained sediments, respectively. The Spisula association can therefore be interpreted as a result of time (successive) and space averaging (adjacent) of these mud and sandy mud communities. 
Values of relative mass-weighted species abundance are compared between units UT2 and UT4. A Kruskal-Wallis test shows significant differences for 7 out of 72 species. Among them, Turritella communis, Thyasira flexuosa, Turbonilla lactea and Lepton squamosum are distinctive of unit UT2. Data about the ecological requirements of these species are quite scarce. It is known, however, that $T$. communis (Yonge, 1946) and $T$. flexuosa (Lopez-Jamar, 1987) live on silt bottoms, whereas T. lactea (Flattely, 1916) and L. squamosum (Salisbury, 1932) prefer sandy bottoms. As described above, these Turritella (mud) and Turbonilla (sandy mud) communities could have combined thanks to time and space averaging, depending on sediment supply. The three other species, Nucula nitidosa, Parvicardium exiguum and Barnea candida, are distinctive of unit UT4. B. candida is a versatile borer that usually lives in hard substrates such as wood or limestone, but can also settle in stiff clay bottoms (Pinn et al., 2005). N. nitidosa is the third most abundant species in the sedimentary record of the western Rade des Trousses. This ubiquitous species usually lives on sandy mud to fine sand bottoms (Allen, 1954), but occasionally may settle on fine mud bottoms and reach very high densities (Tebble, 1966). It is noteworthy that the presentday N. nitidosa population in the Rade des Trousses area (Hily, 1976) is closely restricted to fine sediment which corresponds to that of unit UT4. The few data described above are not sufficient to provide a quantitative palaeoenvironmental reconstruction for the last 2,600 years in the western part of the Rade des Trousses area. Most of the species in the Spisula association have wide ecological requirements with respect to sediment grain-size, salinity, temperature, organic matter content and hydrodynamics. The contrast between sandy mud species ( $T$. communis group in unit UT2) and fine mud species ( $N$. nitidosa group in unit UT4) mirrors the sedimentological data of this record (Fig. 8).

The increasing deposition of fine-grained sediment since 910 years BP has had an unexpected consequence for our present-day knowledge of mollusc communities in the Marennes-Oléron Bay. It has caused the extirpation (i.e. local extinction) of Lepton squamosum, which is only found in unit UT2 (Table 2). This may explain why this already rare species has never been noticed anywhere in the present Marennes-Oléron Bay (de Montaudouin and Sauriau, 2000), despite its wide geographic distribution (Tebble, 1966). A few dead specimens have been dregded by Cianfanelli and Talenti (1987) in the Mediterranean Sea at a depth of $-10 \mathrm{~m}$, together with Thyasira flexuosa. This LeptonThyasira association is supported by our core data (Fig. 10), and has also been observed by Salisbury (1932) in Great-Britain, but to our knowledge, it has never been quantitatively described in live benthic communities.

Preservation of molluscan remains depends on hydrodynamic conditions (currents) and biogenic activity (shell-crushing predators), which are involved in the destruction of shells (e.g. Cadée, 1968). The relative quantity of non-identifiable fragments did not significantly vary between UT2 and UT4 units. It suggests that hydraulic and biogenic breakage either varied throughout time and counterbalanced or remained stable since 2,600 years BP.

\subsection{Level of detail of the palaeoenvironmental interpretations}

The level of detail of the reconstructions varies depending on the composition of fossil assemblages (Table 3). Two main factors determine the distribution of benthic molluscs (Hily, 1976; Sauriau et al., 1989; de Montaudouin \& Sauriau, 1999): bathymetry (intertidal vs. subtidal areas) and sediment grain-size (mud vs. sand, fine vs. coarse sand). The most common species of a fossil assemblage provide raw information about these ecological factors. More detailed information depends on the tolerance of species to variations of a given environmental parameter. Eurytypic species can stand important fluctuations. They have a wide geographical distribution, and thus are likely to disturb an assemblage because of post-mortem transportation of remains. Such noise species contribute to undesired withingroup variability (Fig. 9b, c), which tends to decrease the level of detail of a palaeoenvironmental interpretation. Conversely, sensitive stenotypic species are restricted to particular environmental conditions. Highly detailed, quantitative reconstructions of past 
parameters such as temperature, salinity, and oxygen can be made through the analysis of changes in the distribution of these indicator species.

\subsection{Records of Holocene environmental changes by molluscan assemblages}

\subsubsection{Record of sea level}

In the reference core VC48, the transition from a high (Scrobicularia association) to a low (Rissoa association) intertidal mudflat was interpreted by Allard et al. (2008) as a consequence of the progressive flooding of sub-unit Ue1.2 by the Holocene marine transgression between 8,000 and 7,600 years BP. Due to the presence of many indicator species and the absence of noise species in sub-unit Ue1.2, a highly detailed palaeoenvironmental reconstruction regarding bathymetry, salinity and hydrodynamics was proposed. Allard et al. (2008) used a Scrobicularia plana specimen dated to $8030 \pm 50$ years $\mathrm{BP}$ as a biological indicator of a former Holocene sea level, and their results matched previously published local sea level curves (see Pirazzoli, 1991 for a review). Units Ue1.2 and UT4 show similar seismic facies, as these units are both characterised by sub-horizontal and sub-parallel reflectors (Allard et al., 2008). Grain size analysis of the sediment sampled in these units does not vary significantly too (Allard et al., 2008; Fig. 3). In this case, the mollusc assemblages yielded the most relevant palaeoenvironmental information (Table 3 ), which complemented seismic and sedimentological data.

\subsubsection{Record of hydrodynamic condition changes}

Due to the presence of noise species (Spisula association) and a lower amount of indicator species (Tornus subcarinatus only), the palaeoenvironmental interpretation in unit Ue3 is less quantitative (Table 3). As an example, it is not possible to determine whether if the oyster bank was not located in the lower intertidal or strictly subtidal area, nor could the current speed in this channel be quantitatively estimated. However, the presence of the fragile $T$. subcarinatus suggests that they were weak. The mollusc assemblages suggest that the Ue3 channel was hydraulically inefficient, as early as 5,500 years BP. Such weak tidal currents may be a result of the abandonment of this large and deep channel related to the filling-up of its drainage area with sediment. This is supported by evidence of adjacent marshes sediment-fill that was in progress at this time (Gabet, 1969). Weak currents in this tidal channel are also supported by internal architecture of the Ue3 channel-fill, showing a typical upward decrease in reflectors dip (Fig. 2).

\subsubsection{Record of sediment supply changes}

In the VC14, VC22, VC28 and VC30 sedimentary record, the palaeoenvironmental reconstruction mirror grain size analysis, and is poorly detailed (Table 3). Nevertheless, the sharp transition from sandy mud (UT2) to mud (UT4) communities can be demonstrated by some rare species (Fig. 10), in particular Lepton squamosum. The remarkable stability of both molluscan assemblages and the quantity of well preserved skeletal remains in this area suggests that hydrodynamic conditions did not significantly change since 2,600 years BP. As a sharp change in grain size occurred during this period, it is proposed that the UT4 mud drape can be related to an increase in fine-grained sediment supply rather than a decrease in the hydrodynamic regime. This assumption supports the interpretation of Weber and Chaumillon (2004), deduced from measurements of present-day tidal currents, recorded close to the MOB, which do not show any significant differences in velocities between areas covered by the mud drape and sandy areas located immediately offshore. 


\section{Conclusions}

On the basis of present-day quantitative ecological surveys and knowledge of the ecological requirements of benthic molluscs, Holocene palaeoenvironments in the MarennesOléron bay were described. Besides providing an accurate record of the last Holocene marine transgression, molluscan assemblages also provide new insights into other environmental changes, particularly hydrodynamic conditions and sediment supply. They indicate that a large tidal channel was hydraulically inefficient, suggesting that its tidal drainage area has been filled with sediment as early as 5,500 years BP. They also indicate that the north-western Marennes-Oléron Bay remained stable in terms of hydrodynamic conditions since 2,600 years BP, and that the increase in mud sedimentation that occurred about 1000 years BP may be related to mud supply increase rather than current decrease. The detail level of the palaeoenvironmental reconstructions depends on the ecological requirements of the species. Noise species add undesired variability to the assemblages, whereas indicator species can provide accurate, quantitative information. In any case, molluscs are relevant palaeoenvironmental indicators regarding grain size, bathymetry, salinity, and oxygen content. Thanks to time-averaging, they provide long-term, smoothed records of environment variations. They are also easier to collect and identify than microfossils such as foraminifers. This study suggests that molluscs can be used prior to any other biological proxy, as a first step into reconstructions of Holocene coastal environments.

\section{Acknowledgements}

Vibracore sampling was supported by CNRS-INSU (Institut National des Sciences de I'Univers) and IFREMER. The authors wish to thank the officers and crews of CNRS/INSU Côte de la Manche vessel. Clément Poirier Ph.D. is supported by a MENRT fellowship from the French government. We are indebted to Frank Healy (La Rochelle University) for his advices on English writing. Special thanks are due to Dr Hans G. Hansson (TMBL, Göteborg University) for providing first-hand information about Lepton squamosum ecology, as well as to Françoise Sullet-Nylander for her translation of H.G. Hansson's paper. We gratefully acknowledge Dr. Finn Surlyk, Dr. Franz T. Fürsich and an anonymous reviewer, whose constructive comments helped us to improve the manuscript.

\section{References}

Allard, J., 2008. Enregistrements sédimentaires des forçages eustatiques, climatiques et anthropiques dans la Baie de Marennes-Oléron et la lagune d'Arcachon. Ph.D. thesis, University of La Rochelle, $277 \mathrm{p}$.

Allard, J., Chaumillon, E., Poirier, C., Sauriau, P.-G., Weber, O., 2008. Evidence of former Holocene sea level in the Marennes-Oléron Bay (French Atlantic coast). Comptes Rendus Geosciences 340, 306-314.

Allen, J.A., 1954. A comparative study of British species of Nucula and Nuculana. Journal of the Marine Biological Association of the United Kingdom 33, 457-472.

Bernasconi, M.P., Melis, R., Stanley, J.-D., 2006. Benthic biofacies to interpret Holocene environmental changes and human impact in Alexandria's Eastern Harbour, Egypt. The Holocene 16 (8), 1163-1176.

Bertin, X., Chaumillon, E., 2005. New insights in shallow gas generation from very high resolution seismic and bathymetric surveys in the Marennes-Oléron Bay, France. Marine Geophysical Researches 26, 225-233. 
Billeaud, I., Chaumillon, E., Weber, O., 2005. Evidence of a major environmental change recorded in a macrotidal bay (Marennes-Oléron Bay, France) by correlation between VHR seismic profiles and cores. Geo-Marine Letters 25, 1-10.

Blanchet, H., de Montaudouin, X., Lucas, A., Chardy, P., 2004. Heterogeneity of macrozoobenthic assemblages within a Zostera noltii seagrass bed: diversity, abundance, biomass and structuring factors. Estuarine, Coastal and Shelf Science 61, 111-123.

Borrego, J., Ruiz, F., Gonzalez-Regalado, M.L., Pendón, J.G., Morales, J.A., 1999. The Holocene transgression into the estuarine central basin of the Odiel River mouth (Cadiz gulf, SW, Spain): lithology and faunal assemblages. Quaternary Science Reviews 18, 769-788.

Boucot, A.J., 1981. Principles of Benthic Marine Paleoecology. Academic Press, New York. $463 \mathrm{p}$.

Brett, C.E., Baird, G.C., 1986. Comparative taphonomy: a key to palaeoenvironmental interpretation based on fossil preservation. Palaios 1 (3), 207-227.

Cadée, G.C., 1968. Molluscan biocoenoses and thanatocoenoses in the Ria de Arosa, Galicia, Spain. Zoologische Verhandelingen 95, 1-121.

Chassé, C., Glémarec, M., 1976. Principes généraux de la classification des fonds pour la cartographie bio-sédimentaire. Journal de Recherche Océanographique 1, 1-18.

Chaumillon, E., Tessier, B., Weber, N., Tesson, M., Bertin, X., 2004. Buried sandbodies within present-day estuaries (Atlantic coast of France) revealed by very high resolution seismic surveys. Marine Geology 211, 189-214.

Chaumillon, E., Weber, N., 2006. Spatial variability of modern incised valleys on the French Atlantic Coast: comparison between the Charente and the Lay-Sèvre incised valleys. In: Dalrymple, R.W., Leckie, D.A., Tillman, R.W. (Eds.), Incised Valleys in Time and Space. Society for Sedimentary Geology, Special Publication 85, 57-86.

Cianfanelli, S., Talenti, E., 1987. Ulteriori conoscenze sulla malacofauna del Golfo di Baratti (Piombino - LI). Bollettino Malacologico 23 (5-8), 263-268.

Clavier, J., Chardy, P., 1989. Investigation into the ecology of the ormer (Haliotis tuberculata L.), factors influencing spatial distribution. Aquatic Living Resources 2, 191-197.

Costello, M.J., Emblow, C., White, R., 2001. European Register of Marine Species: a checklist of the marine species in Europe and a bibliography of guides to their identification. Patrimoines Naturels, 50. Muséum National d'Histoire Naturelle, Paris, France.

Davies, D.J., Powell, E.N., Stanton, R.J., 1989. Relative rates of shell dissolution and net accumulation - a commentary: can shell beds form by the gradual accumulation of biogenic debris on the sea floor? Lethaia 22, 207-212.

de Montaudouin, X., Sauriau, P.-G., 1999. The proliferating Gastropoda Crepidula fornicata may stimulate macrozoobenthic diversity. Journal of the Marine Biological Association of the UK 79 (6), 1069-1077.

de Montaudouin, X., Sauriau, P.-G., 2000. Contribution to a synopsis of marine species richness in the Pertuis Charentais Sea with new insights in soft-bottom macrofauna of the Marennes-Oléron bay. Cahiers de Biologie Marine 41, 181-222.

Flattely, F.W., 1916. Notes on the ecology of Cirratulus (Audouinia) tentaculatus (Montagu). Journal of the Marine Biological Association of the United Kingdom 11, 60-70.

Freitas, M.C., Andrade, C., Cruces, A., 2002. The geological record of environmental changes in southwestern Portuguese coastal lagoons since the Lateglacial. Quaternary International 93-94, 161-170.

Fujiwara, O., Kamataki, T., Masuda, F., 2004. Sedimentological time-averaging and ${ }^{14} \mathrm{C}$ dating of marine shells. Nuclear Instruments and Methods in Physics Research B 223-224, 540-544.

Gabet, C., 1969. Le marais de Brouage. Bulletin de la Société de Géographie de Rochefortsur-Mer $2^{\text {ème }}$ série (6), 180-190.

Glémarec, M., 1964. Le genre Abra sur les côtes atlantiques de Bretagne : systématique et écologie. Journal de Conchyologie 104, 15-29.

Gouleau, D., Jouanneau, J.-M., Weber, O., Sauriau, P.-G., 2000. Short- and long-term sedimentation on Montportail-Brouage intertidal mudflat, Marennes-Oléron Bay (France). Continental Shelf Research 20, 1513-1530. 
Goy, J.L., Zazo, C., Dabrio, C.J., Lario, J., Borja, F., Sierro, F.J., Flores, J.A., 1996. Global and regional factors controlling changes of coastlines in Southern Iberia (Spain) during the Holocene. Quaternary Science Reviews 15 (8-9), 773-780.

Graham, A., 1988. Molluscs: Prosobranch and Pyramidellid gastropods. Synopses of the British Fauna 2, 662 pp.

Gruet, Y., Sauriau, P.-G., 1994. Paléoenvironnements holocènes du Marais Poitevin (Littoral Atlantique, France) : reconstitution d'après les peuplements malacologiques. Quaternaire 5, 85-94.

Hily, C., 1976. Ecologie benthique des Pertuis Charentais. Thèse de $3^{\text {ème }}$ cycle, Université de Bretagne Occidentale, Brest, France, $236 \mathrm{pp}$.

Inman, D.L., 1952. Measures for describing size of sediments. Journal of Sedimentary Petrology 19 (2), 125-145.

Ivanova, E.V., Murdmaa, I.O., Chepalyga, A.L., Cronin, T.M., Pasechnik, I.V., Levchenko, O.V., Howe, S.S., Manushkina, A.V., Platonova, E.A., 2007. Holocene sea-level oscillations and environmental changes on the Eastern Black Sea shelf. Palaeogeography, Palaeoclimatology, Palaeoecology 246, 228-259.

Kidwell, S.M., 2002. Time-averaged molluscan death assemblages: Palimpsests of richness, snapshots of abundance. Geology 30 (9), 803-806.

Lastra, M., Sanchez, A., Mora, J., 1993. Population dynamics and secondary production of Parvicardium exiguum (Gmelin, 1790) in Santander Bay ( $\mathrm{N}$ of Spain). Journal of Molluscan Studies 59, 73-81.

Long, A.J., Scaife, R.G., Edwards, R.J., 2000. Stratigraphic architecture, relative sea-level, and models of estuary development in southern England: new data from Southampton Water. In: Pye, K., Allen, J.R.L., (eds.), Coastal and Estuarine Environments: Sedimentology, geomorphology and geoarchaeology. Geological Society, London, Special Publications 175, 253-279.

Lopez-Jamar, E., Gonzalez, G., Mejuto, J., 1987. Ecology, growth and production of Thyasira flexuosa (Bivalvia, Lucinacea) from Ria de la Coruña, North-West Spain. Ophelia 27 (2), 111-126.

Migeon S., Weber O., Faugères J.-C., Saint-Paul J., 1999. SCOPIX: A new X-ray imaging system for core analysis. Geo-Marine Letters 18, 251-255.

Pérès, J.-M., Picard, J., 1964. Nouveau manuel de bionomie benthique. Recueil des Travaux de la Station marine d'Endoume 31 (47), 5-137.

Pinn, E.H., Richardson, C.A., Thompson, R.C., Hawkins, S.J., 2005. Burrow morphology, biometry, age and growth of piddocks (Mollusca: Bivalvia: Pholadidae) on the south coast of England. Marine Biology 147, 943-953.

Pirazzoli, P.A., 1991. World atlas of Holocene sea-level changes. Elsevier, Amsterdam, 280 pp.

R Development Core Team, 2008. R: A language and environment for statistical computing. $\mathrm{R}$ Foundation for Statistical Computing, Vienna, Austria. ISBN 3-900051-07-0, URL http://www.r-project.org.

Raillard, O., Ménesguen, A., 1994. An ecosystem box model for estimating the carrying capacity of a macrotidal shellfish system. Marine Ecology Progress Series 115, 117-130.

Salisbury, A.E., 1932. On Lepton squamosum (Montagu) and Montacuta ferruginosa (Montagu) and some other molluscs observed in the Salcombe estuary, Devon. Journal of Molluscan Studies 20, 100-103.

Sauriau, P.-G., Gruet, Y., 1988. Essai de reconstitution d'un paléoenvironnement récent dans le Marais Poitevin (Charente-Maritime). Haliotis 18, 9-20.

Sauriau, P.-G., Mouret, V., Rincé, J.-P., 1989. Organisation trophique de la malacofaune benthique non cultivée du bassin ostréicole de Marennes-Oléron. Oceanologica Acta, 12 (2), 193-204.

Taldenkova, E., Bauch, H.A., Stepanova, A., Dem'yankov, S., Ovsepyan, A., 2005. Last postglacial environmental evolution of the Laptev Sea shelf as reflected in molluscan, ostracodal, and foraminiferal faunas. Global and Planetary Change 48, 223-251. 
Tebble, N., 1966. British Bivalve Seashells: A Handbook Identification. British Museum, London, $212 \mathrm{pp}$.

Valentine, J.W., Jablonski, D., Kidwell, S.M., Roy, K., 2006. Assessing the fidelity of the fossil record by using marine bivalves. Proceedings of the National Academy of Sciences 103 (17), 6599-6604.

Weber, N., Chaumillon, E., 2004. Long term evolution of sandwaves in estuaries demonstrated by active, intermediate and moribund sandwaves of French Atlantic coast (Charente-Maritime). In: Hulscher, S., Garlan, T., Idier, D. (Eds.), Marine Sandwaves and River Dune Dynamics II International Workshop, SHOM, University of Twente - The Netherlands, 314-321.

Welsh, J., 1919. L'argile à Scrobiculaire des marais maritimes du centre-ouest de la France. Bulletin de la Société Géologique de France 4, 46-61.

Wolff, W.J., 1973. The estuary as a habitat: an analysis of data on the soft-bottom macrofauna of the estuarine area of the Rivers Rhine, Meuse, and Scheldt. Zoologische Verhandelingen 126, 3-242.

Yonge, C.M., 1946. On the habits of Turritella communis Risso. Journal of the Marine Biological Association of the United Kingdom 26 (3), 377-380.

Ysebaert, T., de Neve, L., Meire, P., 2000. The subtidal macrobenthos in the mesohaline part of the Schelde Estuary (Belgium): influenced by man? Journal of the Marine Biological Association of the United Kingdom 80, 587-597.

Zinke, J., Reijmer, J.J.G., Taviani, M., Dullo, W.-C., Thomassin, B., 2005. Facies and faunal assemblage changes in response to the Holocene transgression in the Lagoon of Mayotte (Comoro Archipelago, SW Indian Ocean). Facies 50, 391-408. 


\section{Tables}

Species

Abra nitida

Corbula gibba

Kurtiella bidentata

Antalis novemcostata

Nassarius pygmaeus

Nucula nitidosa

Cylichna cylindracea

Spisula solida

Turritella communis

Nassarius reticulatus

Crepidula fornicata

Spisula subtruncata

Solen marginatus

Retusa truncatula

Philine aperta

Abra alba

Chlamys varia

Melanella alba

Nassarius incrassatus

Pholadidea loscombiana

Hyala vitrea

Macoma balthica

Pandora inaequivalvis

Chamelea striatula

Acanthocardia paucicostata
Mud

community
Sandy mud

community
50.6

28.8

1.0

6.7

6.3

3.3

0.0

0.0

0.0

0.0

0.0

3.3

0.0

0.0

0.0

0.0

0.0

0.0

0.0

0.0

0.0

0.0

0.0

0.0

0.0
28.4

\section{2}

24.6

2.8

6.1

6.0

5.3

0.5

3.6

3.2

2.9

2.1

1.7

1.0

0.9

0.6

0.5

0.5

0.5

0.5

0.4

0.3

0.3

0.2

0.1

Table 1

Composition of present-day molluscan communities (mean relative abundance) in the Rade des Trousses area described by de Montaudouin and Sauriau (1999). Highest values for each row are in bold. 
Species

Mean value

Mean

value

$p$ value

in unit UT2 (\%)

in unit UT4 (\%)

Nucula nitidosa

$2.9 \pm 3.3$

$15.6 \pm 22.4$

0.025

Parvicardium exiguum

$<0.1 \pm 0.1$

$0.1 \pm 0.4$

0.018

Barnea candida

0.0

$0.1 \pm 0.3$

0.002

Turritella communis

$5.3 \pm 17.7$

$1.8 \pm 7.5$

0.045

Turbonilla lactea

$0.4 \pm 0.8$

$<0.1 \pm 0.1$

0.004

Thyasira flexuosa

$0.3 \pm 1.1$

$<0.1 \pm 0.1$

0.001

Lepton squamosum

$<0.1 \pm 0.1$

0.0

0.015

\section{Table 2}

Results of Kruskal-Wallis tests performed on relative mass-weighted species abundance (mean values \pm standard error). Highest values for each row are in bold.

Assemblage Interpretation Indicator species for Noise species from Level of detail

Scrobicularia Higher intertidal bathymetry,

$++$

(sub-unit Ue1.2) mudflat

salinity,

hydrodynamics

Rissoa Lower intertidal bathymetry,

(sub-unit Ue1.2) mudflat salinity,

hydrodynamics

Ostrea-Tornus

Oyster bank

oxygen,

Spisula

$+-$

(unit Ue3)

hydrodynamics

association

Spisula

Shallow water

Tornus, Ostrea

(unit UT2)

subtidal area

and Rissoa

associations

Spisula

Shallow water -

Tornus, Ostrea

(unit UT4)

subtidal area

and Rissoa

associations

Table 3

Features of the palaeoenvironmental reconstructions $(++$ : good level of detail, +- : moderate level of detail, --: poor level of detail). 


\section{Figures}

Fig. 1. Location of the study area. (a) Map of France. (b) Map of the Marennes-Oléron Bay, with $10 \mathrm{~m}$ bathymetric interval and toponyms cited in the text. (c) Map of the Rade des Trousses area, with location of the selected seismic profiles in bold and the six selected cores. Coordinates are given according to the WGS84 geodetic system.

Fig. 2. Synthetic fence diagram of very high resolution seismic profiles showing the sedimentary fill of the Marennes-Oléron Bay (modified from Chaumillon et al.,2004; Billeaud et al., 2005; Bertin and Chaumillon, 2005; Chaumillon and Weber, 2006 and Allard et al., 2008). Heavy black line corresponds to EU1 erosional unconformity. Location of the six selected cores along seismic profiles is indicated.

Fig. 3. Sedimentological data of cores VC48 and VC47. From left to right, for each core: elevation in metres (NGF elevation system), stratigraphic units, X-ray image, biogenic features, median grain size in micrometres, synthetic log of grain size. On lower left: Detail of Fig. 2 showing location of cores VC48 and VC47 along seismic profile M4b38.

Fig. 4. Sedimentological data of cores VC14, VC22, VC28 and VC30. From left to right, for each core: elevation in metres (NGF elevation system), stratigraphic units, X-ray image, biogenic features, median grain size in micrometres, synthetic log of grain size, bulk samples. On lower left: Detail of Fig. 2 showing location of cores along seismic profiles LSTULR6-33 and LSTULR6-37. Dashed lines indicate correlations between sediment facies.

Fig. 5. Principal Component Analysis plots of loadings performed on relative species abundance. (a) Components 1 and 2. (b) Components 1 and 3.

Fig. 6. Synthetic log of reference core VC48. From left to right: elevation in metres (NGF elevation system), stratigraphic units, synthetic log of grain size, uncalibrated radiocarbon ages, bulk samples, total species richness, presence-absence matrix. Black cells indicate the presence of a species in a sample, and grey cells indicate its absence. Diamond dots indicate bulk samples from which mollusc specimens or valves were chosen for radiocarbon dating. Light-grey shaded areas represent parts of the core that were not taken into account for data analysis (i.e. Taphonomically Active Zone and EU1 shell bed).

Fig. 7. Synthetic log of core VC47. From left to right: elevation in metres (NGF elevation system), stratigraphic units, synthetic log of grain size, uncalibrated radiocarbon ages, bulk samples, total species richness, presence-absence matrix. Black cells indicate the presence of a species in a sample, and grey cells indicate its absence. Diamond dots indicate bulk samples from which mollusc specimens or valves were chosen for radiocarbon dating. Lightgrey shaded areas represent parts of the core that were not taken into account for data analysis (i.e. Taphonomically Active Zone and EU1 shell bed).

Fig. 8. Synthetic log of cores VC14, VC22, VC28 and VC30. From left to right: elevation in metres (NGF elevation system), stratigraphic units, grain size synthetic log, uncalibrated radiocarbon ages, bulk samples, total species richness, presence-absence matrix. Black cells indicate the presence of a species in a sample, and grey cells indicate its absence. Diamond dots indicate bulk samples from which mollusc specimens or valves were chosen for radiocarbon dating. Light grey shaded areas represent parts of core that were not taken into account for data analysis (i.e. Taphonomically Active Zone and EU1 shell bed).

Fig. 9. Principal Component Analysis plots of scores performed on relative species abundance (components 1 and 2). (a) Reference core VC48. (b) Core VC47. (c) Cores VC14, VC22, VC28 and VC30. 
Fig. 10. Plots of relative mass-weighted species abundance in cores VC14, VC22, VC28 and VC30. Light-grey shaded areas represent parts of the core that were not taken into account for data analysis (i.e. Taphonomically Active Zone and EU1 shell bed). 
$\Lambda^{N}$

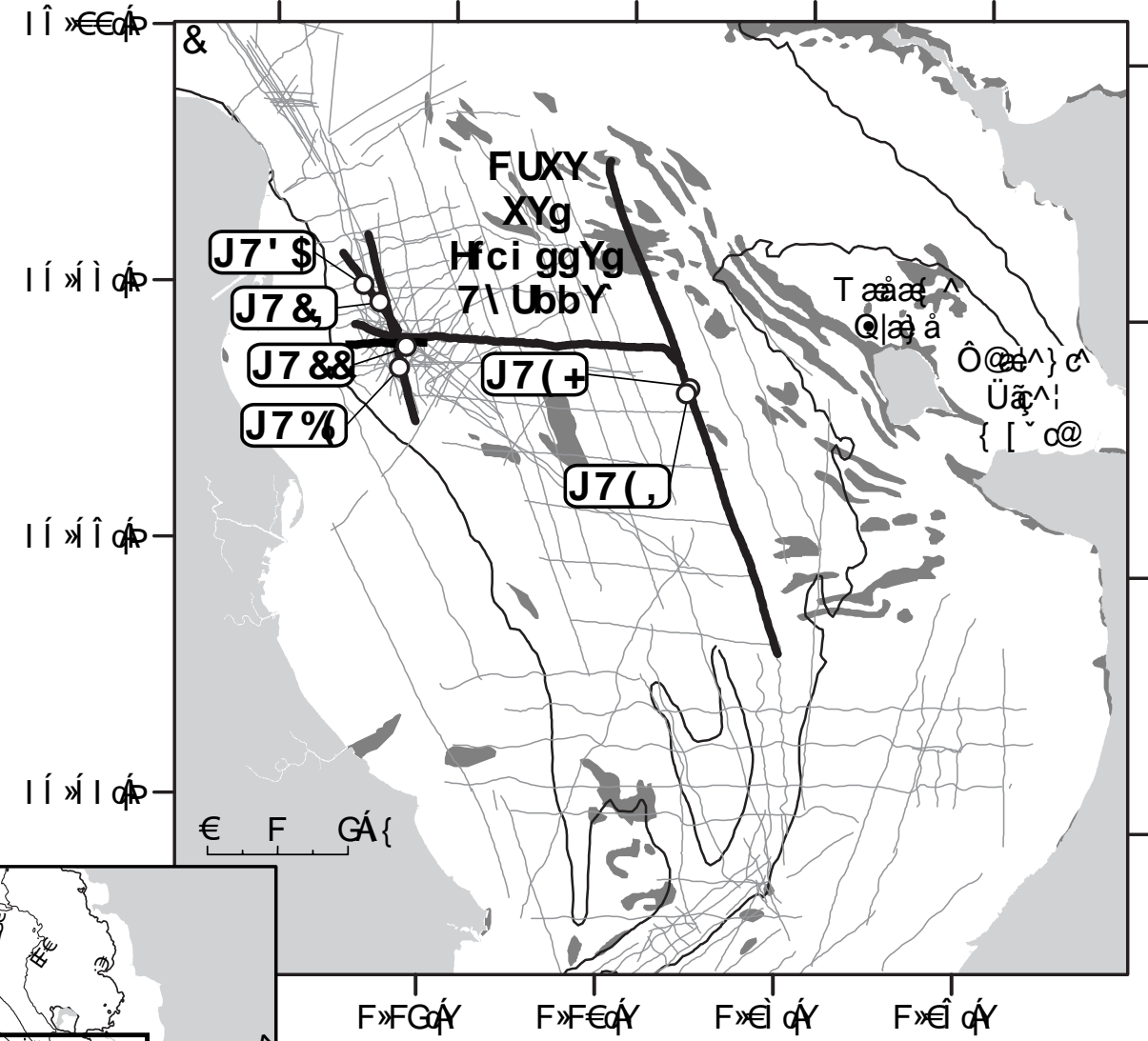

ฐ France

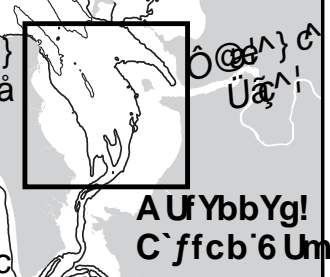

$\sim 0 \mathrm{~m}$ isobath (b and c maps)

$\sim 10$ m bathymetric interval (b map)

rocky outcrops

selected seismic profiles (c map, figure 2)

_ other seismic profiles from the area (c map)

cores 


\section{VC48}

$-7$

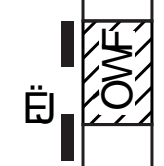

Im NGF

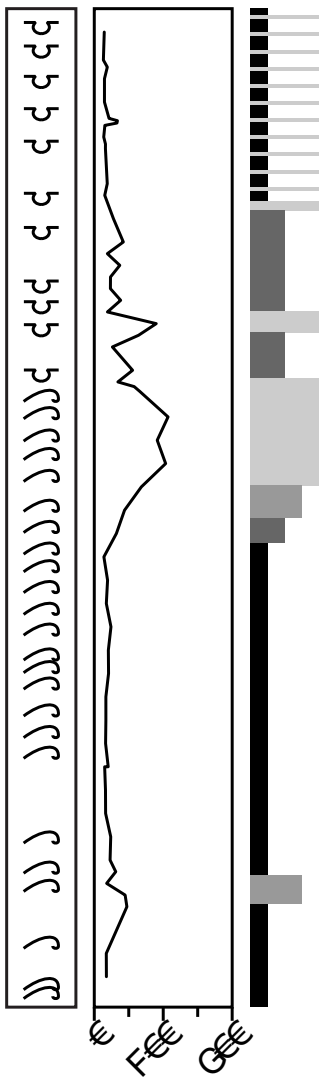

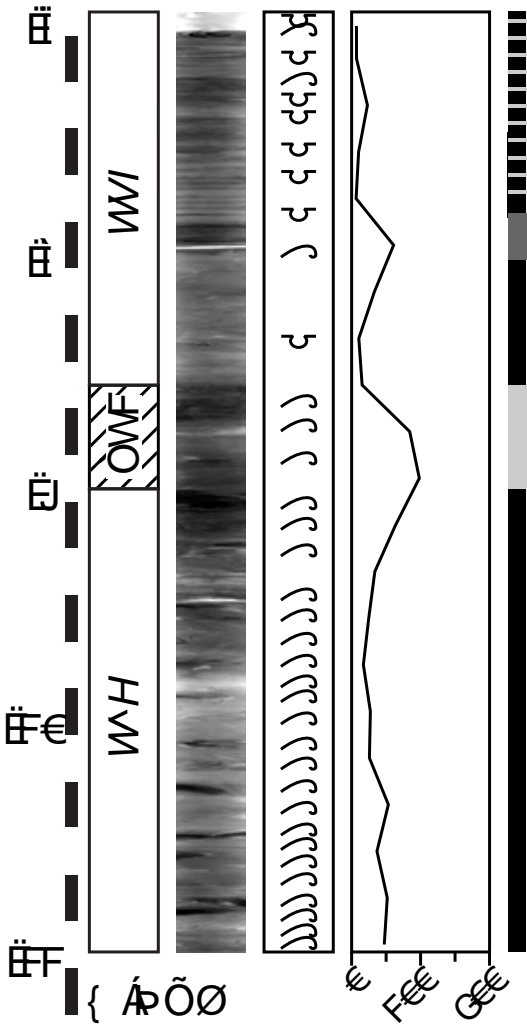

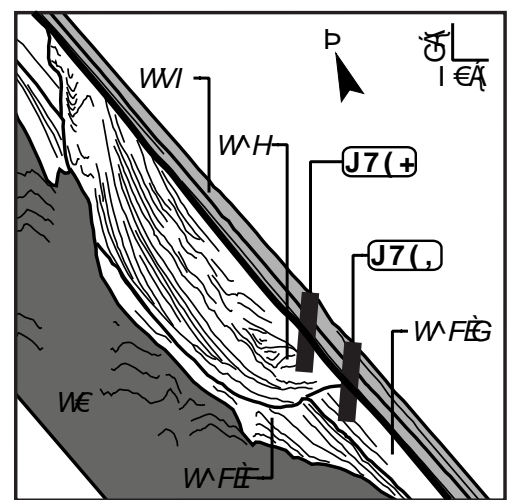

Facies

- clay to fine silt (<15 Õm)

- medium silt (15ï 30 Õm)

- coarse silt (30ï 63 Õm)

very fine to fine sand (>63 Õm)

\section{Structures}

- silt-sand altemations

$\checkmark$ bioturbation signs

$\supset$ mollusc skeletal remains 


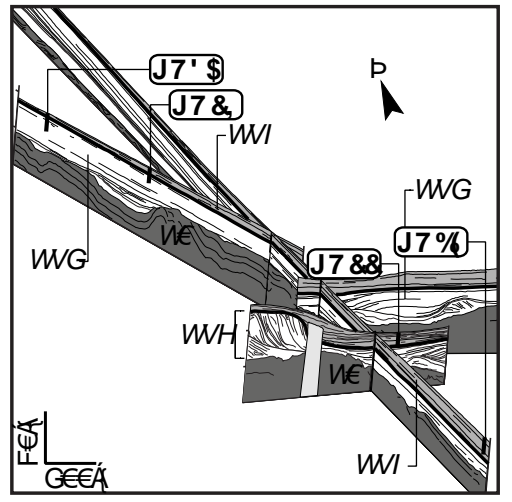

VC14

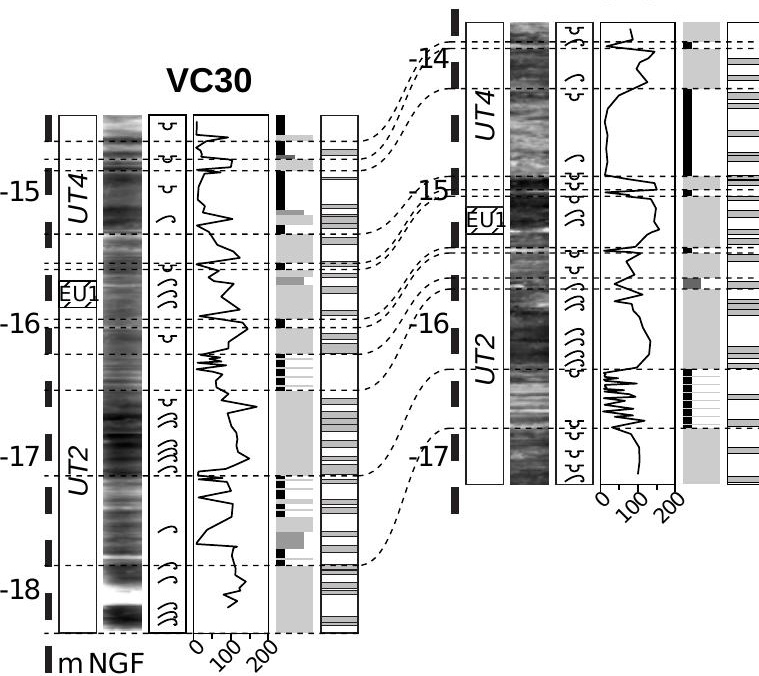

Facies

- clays to fine silt (<15 Õm)

- medium silt (15ï 30 Õm)

- coarse silt (30ï 63 Õm)

very fine to fine sand (>63 Õm)

\section{Structures}

- silt-sand alternations

$\checkmark$ bioturbation signs

$\frown$ mollusc skeletal remains 


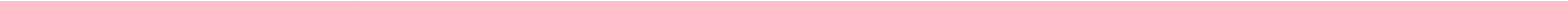




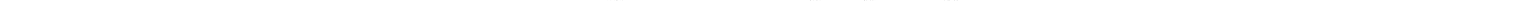



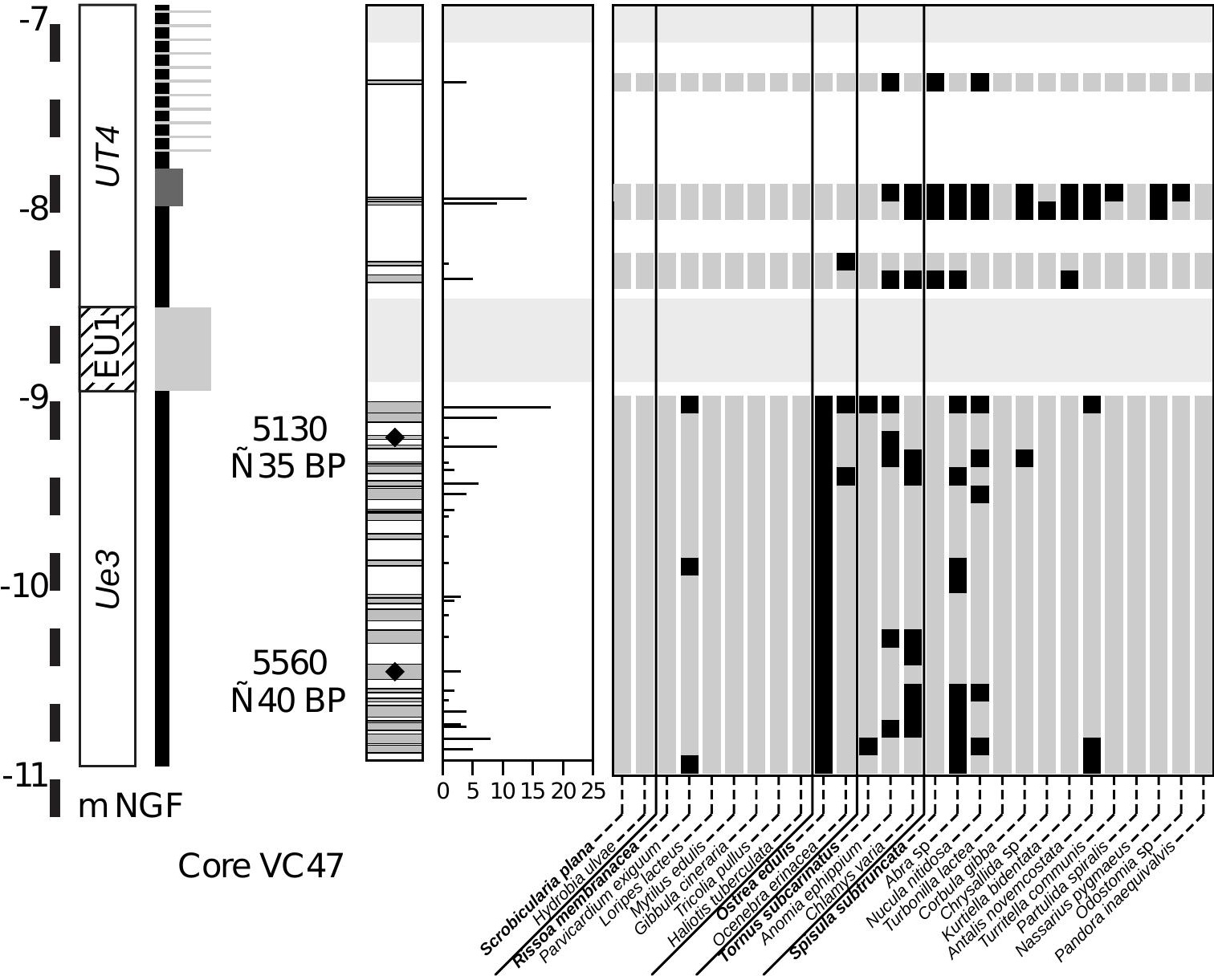


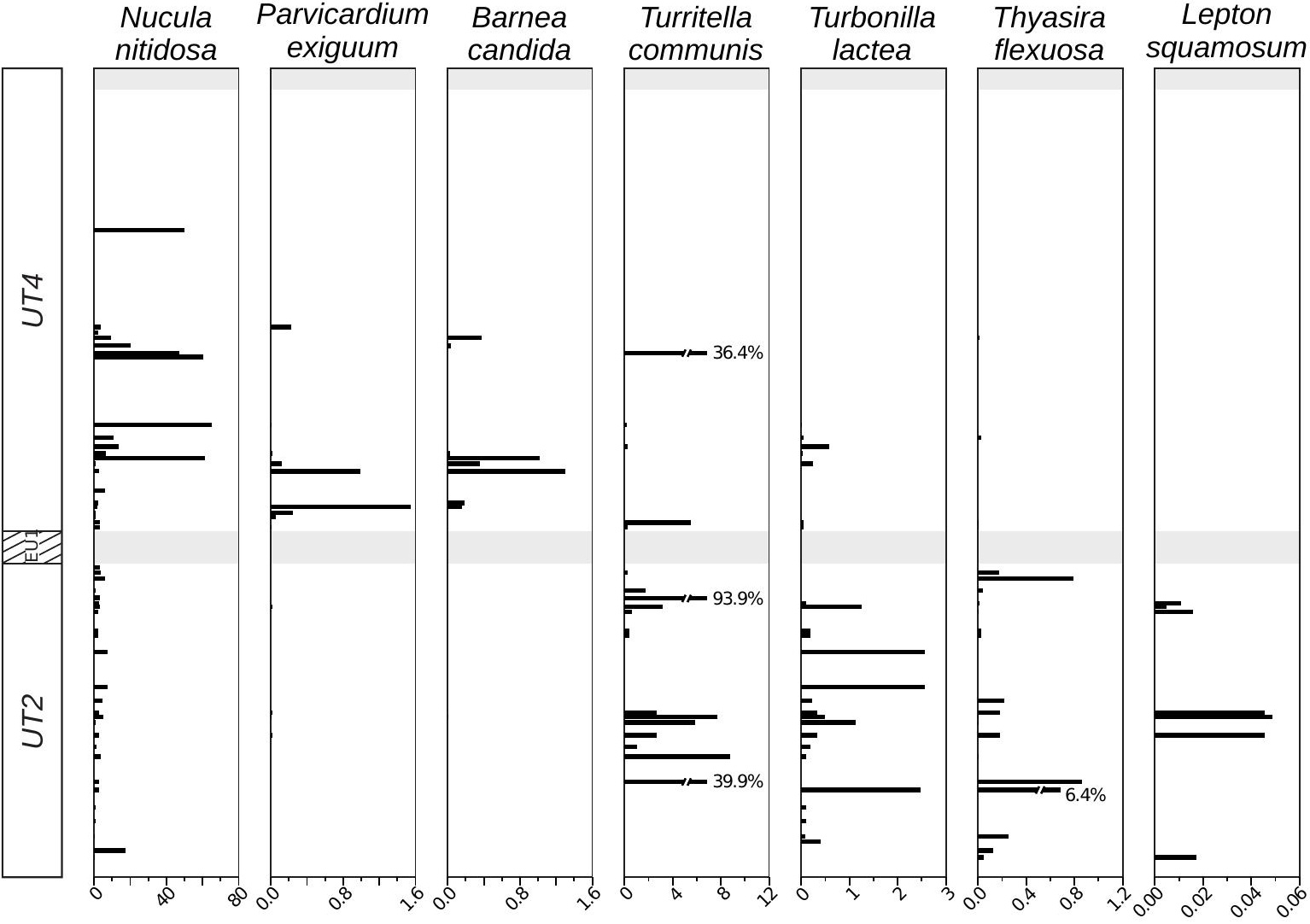

